\title{
An Early Cretaceous vertebrate assemblage from the Cabao Formation of NW Libya
}

\author{
JEAN LE LOEUFF*, EDDY MÉTAIS $\dagger$, DIDIER B. DUTHEIL $\ddagger$ JEAN LOUP RUBINO $\S$, \\ ERIC BUFFETAUT $\uparrow$, FRANÇOIS LAFONT $\S$, LIONEL CAVIN\|, FABRICE MOREAU\#, \\ HAIYAN TONG**, CHRISTIAN BLANPIED $\dagger \&$ ALI SBETA $\dagger$
}

* Musée des dinosaures, 11260 Espéraza, France

$\dagger$ Total, Tour Coupole, Paris la Défense, France

$\ddagger 15$, passage du Buisson Saint-Louis, 75010 Paris, France

$\S$ Total, CSTJF, Avenue Larribau, 64018 Pau Cedex, France

ๆCNRS, Ecole Normale Supérieure, 24 rue Lhomond, 75231 Paris cedex 05, France

||Muséum d'Histoire Naturelle, 1 route de Malagnou, 1208 Genève, Switzerland

\#Domaine de la Grange, 37110 Les Hermites, France

**30 rue Carnot, 94270 Le Kremlin-Bicêtre, France

††Geology Department, University of El Fateh, Tripoli, Libya

(Received 21 November 2009; accepted 18 January 2010; First published online 10 March 2010)

\begin{abstract}
Fossil vertebrates from the Cabao Formation discovered in the area of Nalut in northwestern Libya include the hybodont shark Priohybodus, the crocodilian Sarcosuchus, an abelisaurid, a baryonichine spinosaurid and a large sauropod with spatulate teeth. The Cabao Formation may be Hauterivian to Barremian in age, although an earlier Berriasian to Valanginian age cannot be excluded. Its dinosaur assemblage is reminiscent of that of the El Rhaz and Tiouraren formations of Niger and strongly differs from both the Cenomanian assemblages of Morocco and Egypt and the Late Aptian to Albian fauna of Tunisia. Fossil vertebrates may be an important tool to establish the stratigraphical framework of the poorly dated Early Cretaceous continental deposits of Africa.
\end{abstract}

Keywords: Early Cretaceous, Libya, dinosaurs, biostratigraphy.

\section{Introduction}

Early Cretaceous vertebrates are still poorly known in Africa, where the most important Cretaceous localities are Cenomanian in age in Egypt and Morocco (Stromer, 1936; Smith et al. 2001; Cavin et al. 2010; Taquet, 1976). Earlier sites of the 'Continental Intercalaire' (a name suggested by Kilian in 1931 to designate the Palaeozoic and Mesozoic continental levels located between the latest marine Palaeozoic rocks and the Cenomanian transgression across the Sahara desert) in Niger (Taquet, 1976; Sereno et al. 1994), Mali (O'Leary et al. 2004), Algeria and several other places (see Rauhut \& Lopez-Arbello, 2009 for a recent review) are still extremely poorly dated because of the absence of marine incursions during the early Cretaceous in these areas. Other Early Cretaceous sites have been recognized in Tunisia (Bouaziz et al. 1988; Benton et al. 2000; Srarfi et al. 2004; D. Srarfi, unpub. Ph.D. thesis, Univ. Claude Bernard, Lyon, 2006), where some marine intercalations can help to pin down their age.

In the course of sedimentological field work for TOTAL Libye, one of us (EM) discovered several rich assemblages of fossil vertebrates in the Cabao Formation in NW Libya (surface collecting). This material is described herein. The discovery of anteAlbian vertebrates in Libya is of great interest for our

*Author for correspondence: jeanleloeuff@yahoo.fr understanding of the succession of early Cretaceous vertebrate assemblages in Africa, as some correlations can be made with the neighbouring assemblages of Southern Tunisia, the age of which is discussed below.

\section{A short history of true and mythical discoveries of vertebrates in the Early Cretaceous of Libya}

According to several authors (Robaux et al. 1942; Lapparent, 1951, 1960; Ouaja et al. 2002; Srarfi et al. 2004; D. Srarfi, unpub. Ph.D. thesis, Univ. Claude Bernard, Lyon, 2006), Early Cretaceous continental vertebrates were first recognized in Libya by Italian geologists, who described fossil fishes in the deposits of the 'Continental Intercalaire'. This mention of 'Italian authors' can be traced originally to Robaux et al. (1942), and was then cited by later authors. In this paper (the notice of a hydrogeological map of southern Tunisia; original pamphlet undated and perhaps effectively published in 1942 or 1943), Robaux et al. mention the recent discovery of a 'rich fish fauna made in Tripolitania and recently described by Italian authors which leaves no doubt about the Wealden age of these deposits; these fishes are as follows:' (translation from the French by the authors) but the text stops here without any list following the colon. In a long erratum kept at the Société géologique de France in Paris, it is noted that this publication was made difficult by the 
'1943 Tunisian events' which prevented the authors from correcting the proofs. The so-called events are related to some episodes of the Second World War in North Africa, when German and Italian troops invaded the French protectorate of Tunisia at the end of 1942, before they had to leave the country in 1943 following the battle of El Alamein. Their defeat led to the departure of Italians from Libya and the closure of their geological institutions in Africa. However, we could not find a single original reference in the Annali del Museo Libico di Storia Naturale about these purported discoveries of fishes, and Desio (1950) in his bibliography of the geology of Libya does not mention Early Cretaceous ('Wealden') fossil fishes found by Italian geologists. It thus seems likely that Robaux et al. would have heard about discoveries of fossil fishes in Tripolitania by Italian colleagues, which were never published and soon forgotten following the collapse of Italian colonies in North Africa. An alternative possibility is that Robaux et al. mistakenly mentioned fishes when referring to Sassi's recent (1942) report of Wealden plants in the Early Cretaceous of Libya. Although a forgotten publication in some obscure journal cannot be excluded, we suspect that one of our hypotheses is correct. Lapparent was thus the first author to report Early Cretaceous vertebrates from Libya in 1960; he mentioned several sites discovered by him along the Dahar escarpment in South Tunisia and Tripolitania (northwestern Libya) during a field trip in 1951, on the tracks of the French geologist Pervinquières who was the first, in 1912, to describe fossil vertebrates from the same horizons in southern Tunisia. In Libya, Lapparent mentions several localities in Nalut, Giado, Iefren and Garian. The Giado locality yielded a theropod tooth and a bone referred by him to Elaphrosaurus iguidiensis. Other sites provided fishes and crocodiles only and were not described in detail by Lapparent. Later, Burollet \& Manderscheid (1965) mentioned teeth and jaws of crocodiles from the Cabao Formation. Hammuda mentioned in 1969 a crocodile tooth found at Wadi al-Mezaida near Giado. The Libyan geologist El-Zouki (1980) later figured various teeth and scales referred to fishes, turtles and crocodiles as well as a dinosaur vertebra from the Cabao Formation in a sand quarry at Jannawan, near Giado. Although El-Zouki refers this material to Spinosaurus (?), the published plate (a vertebral centrum in ventral view) does not allow any precise assessment. More recently, Smith \& Dalla Vecchia (2006) described a possible abelisaurid tooth collected by an Italian amateur palaeontologist near Nalut (see also Dalla Vecchia, 1995 for a preliminary description of this tooth). The same locality has yielded abundant material of the hybodont shark Priohybodus described by Duffin in 2001. This material has been found, according to Duffin (2001) and Smith \& Dalla Vecchia (2006), in the Kiklah Formation, which overlies the Cabao Formation, but our own investigations in this area suggest that this material comes rather from the Cabao Formation. Smith et al. (2006) and Smith \& Lamanna (2009), in

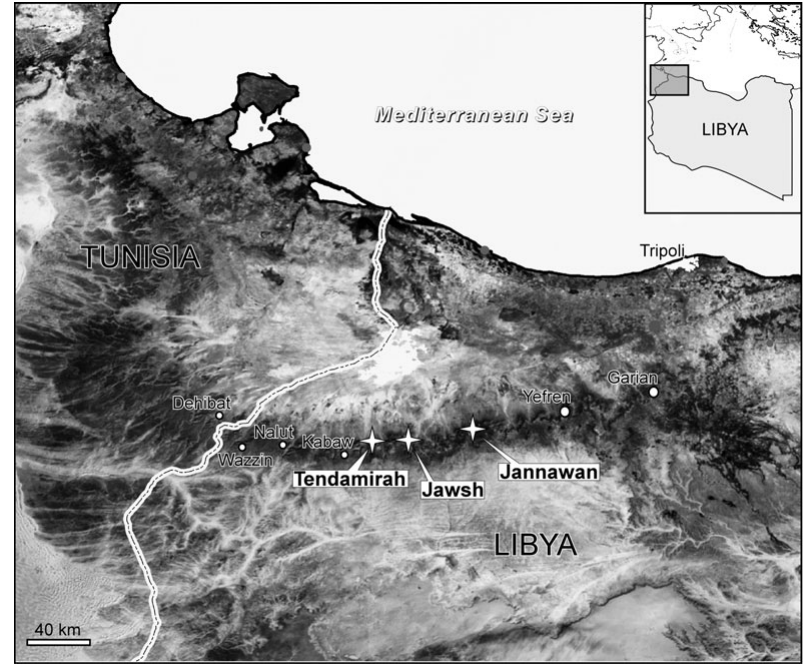

Figure 1. Location map.

two abstracts, briefly reported more discoveries in the Cabao and Kiklah formations, including abelisauroid bones, a possible titanosauriform, along with shark, turtle, lungfish and crocodyliform remains.

\section{Geology}

Several sand quarries located along the northern border of the Jabal Nafusah have yielded vertebrate remains. The material described here was found in three quarries: Tendamirah, Jawsh and Jannawan (Fig. 1). These are all opened in the Cabao Formation, a continental to shallow marine unit (estuarine with tidal influences on depositional settings: cf. Rubino et al. 2009) first described by Burollet in 1963 (Burollet, $1963 a, b)$, near the village of Giado. At this locality, it directly overlies the marine Late Jurassic Shakshuk Formation and underlies the Kiklah Formation (Fig. 2), a possible lateral equivalent of the Oum ed Diab and Chenini members of the Aïn Guettar Formation of southern Tunisia considered as Late Aptian to Albian in age (see Ouaja et al. 2002). Since that time, this stratigraphic succession has been adopted by all authors working in Djebal Nefusah (Hammuda, 1969; ElZouki, 1980; Fatmi, Eliagoubi \& Hammuda, 1980), but eight sedimentological sections logged between the Giado locality and the Tunisian border clearly demonstrate that an intermediate sandy and shaly interval appears and develops between the Shakshuk and Cabao formations in this area (Fig. 3). This series, up to $120 \mathrm{~m}$ thick is topped by a distinct member of lagoonal green shales and dolomites that clearly corresponds to the Douiret shale, first described in southern Tunisia by Busson in 1967 and ranged more recently in the upper Douiret Formation by Ouaja et al. (2002). This additional interval intercalated between the Shakshuk and the Cabao formations is herein mentioned for the first time in Libya and should be considered as the lateral equivalent of the Tunisian Boulouha and Douiret formations (see 


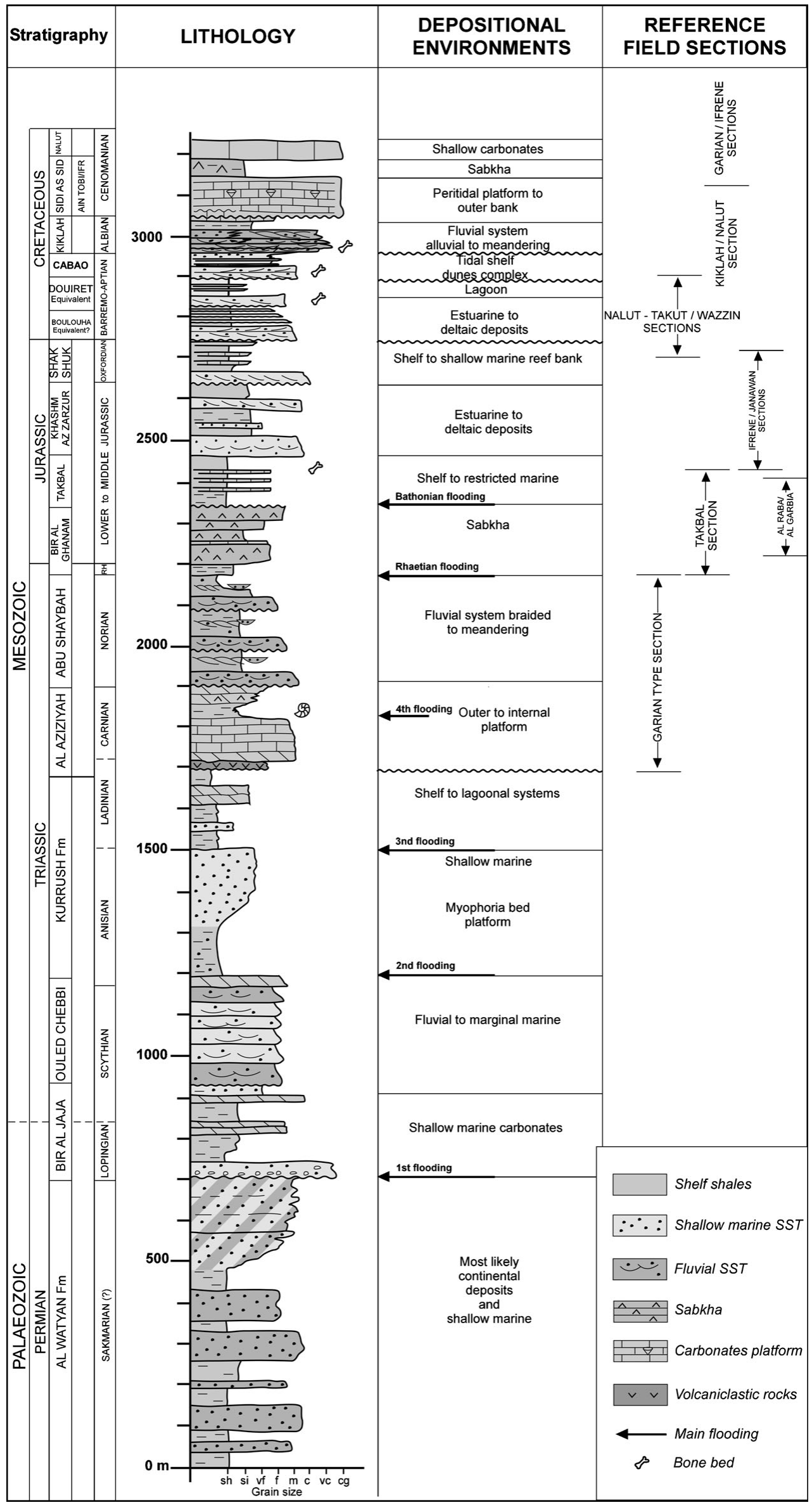

Figure 2. Composite stratigraphical section of the Jabal Nafusah, NW Libya. 


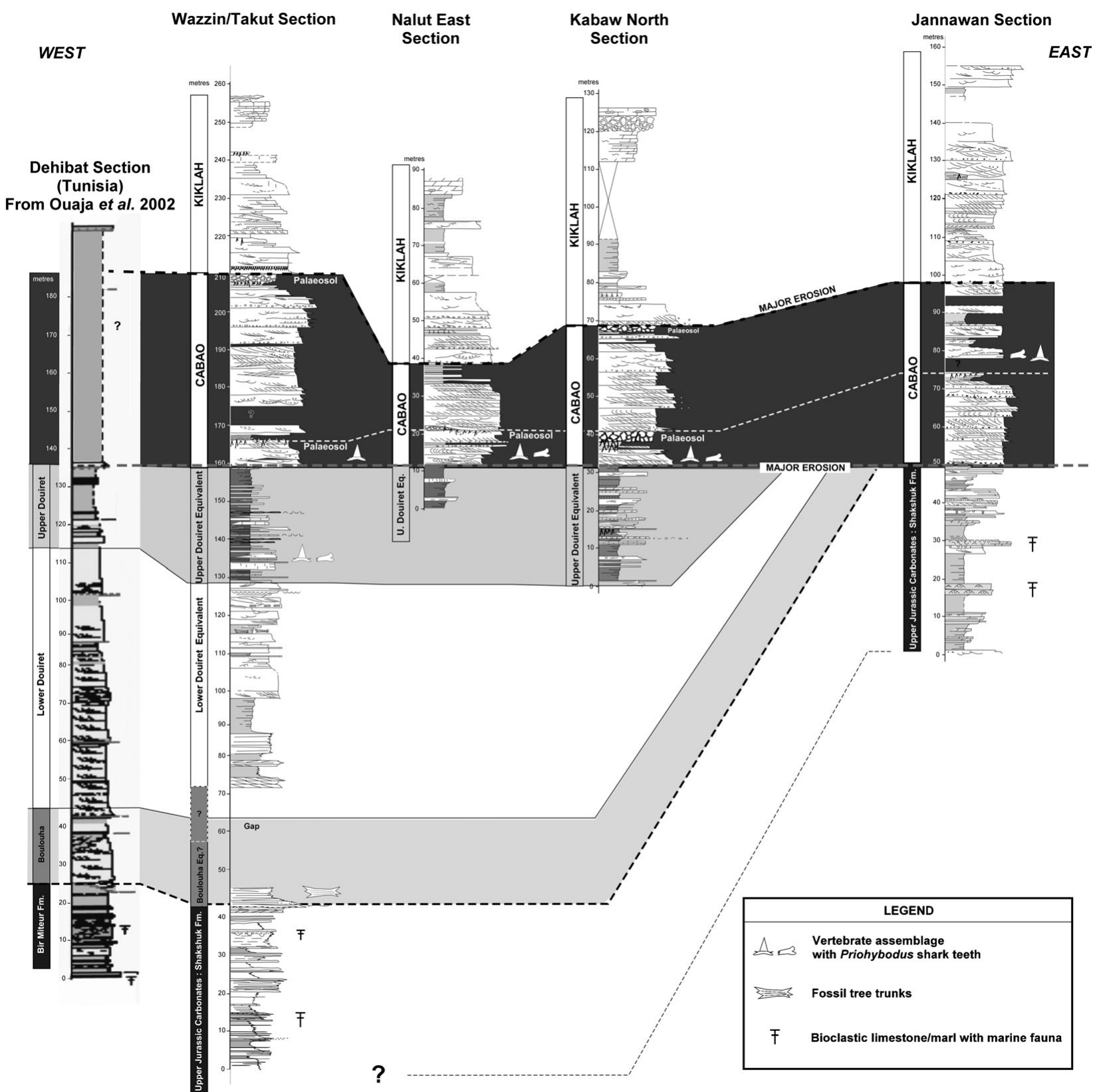

Figure 3. Lithostratigraphical correlation between Jannawan, Wazzin (Tunisian-Libyan border) and Dehibat (SE Tunisia) sections. Dehibat section is from Ouaja et al. 2002 (modified). Horizontal aspect not to scale. Distance between Dehibat and Jannawan: $120 \mathrm{~km}$.

Dehibat section, modified from Ouaja et al. 2002 in Fig. 3). The overlying Cabao Formation would itself be contemporaneous with the sandstones overlying the Douiret shales in Tunisia and appearing south of Touil el Hira ('Barremian sandstones' of Busson, 1967) and later attributed to the Chenini Formation by Bouaziz et al. (1988) and Ouaja et al. (2002). We suspect that only the uppermost part of this sandy interval should be considered as the Aptian-Albian Chenini Formation (see Fig. 3).

Tunisian geologists refer the Douiret Formation to the Aptian or Barremo-Aptian. This age assignment is based on its geometric position above Hauterivian to Barremo-Bedoulian levels of the Boulouha Formation (the latter being dated by the occurrence of the Late Hauterivian to Early Aptian (Bedoulian) rhynchonellid
Loriolithyris russillensis: cf. Peybernès et al. 1996) and below the Chenini member of the Upper Aptian to Albian Aïn Guettar Formation. The Douiret Formation is thus generally considered as Barremo-Aptian in age by Tunisian geologists (Ouaja et al. 2002; Srarfi et al. 2004). However, the brachiopod L. russilensis has also been described from older Berriasian strata in Algeria (Benest, Gaspard \& Gali, 1996), which would rather suggest an age somewhere between the Berriasian and the Early Aptian for the Boulouha and the Douiret formations and the overlying lowermost sandstone interval in Tunisia, equivalent of the Cabao Formation. The fossil content of the Douiret Formation can help to constrain its age: the absence of angiosperms in its flora (Barale \& Ouaja, 2002) would also suggest an age older than Aptian. The microvertebrates from 
the Douiret Formation are known from the Late Jurassic to the Aptian, the youngest record of several taxa being in the Hauterivian or Barremian (G. Cuny, pers. comm.): the latest ascertained record of Egertonodus is in the Barremian (Rees \& Underwood, 2008); Caturus has been found in the Barremian of Spain (Buscalioni et al. 2008) but not later, and the youngest record of Gyrodus is in the Hauterivian of Germany (Kriwet \& Schmitz, 2005). This faunal assemblage thus strongly suggests a pre-Aptian age for the Douiret Formation; the macrofauna does not yield useful stratigraphical information. In all likelihood, a Hauterivian to Barremian age is plausible for the Douiret Formation, although an older Berriasian or Valanginian age cannot be completely excluded.

\section{Vertebrates from the Cabao Formation}

The material described in this paper belongs to the collections of the Geology Department at the University Al Fateh in Tripoli, Libya (abbreviation: UT).

\section{4.a. Sharks and bony fishes}

The fish assemblage is composed of hybodonts ( $\mathrm{Hy}$ bodus sp., Priohybodus arambourgi), actinopterygians (Semionotiformes indet.), and sarcopterygians with one dipnoan (Ceratodontidae, a large tooth) and a mawsoniid coelacanth. Teeth of the hybodont shark Priohybodus arambourgi are extremely abundant in most localities of the Cabao Formation, whereas this species is conspicuously absent from the overlying Kiklah Formation. Priohybodus is known only from East and Northeast Africa (Somalia, Ethiopia, Tunisia, Libya) in the Late Jurassic and the Early Cretaceous but is unknown from the contemporaneous localities of West Africa. This might suggest some kind of endemism for this freshwater hybodont but its recent discovery in probably Late Jurassic levels in Uruguay (Perea et al. 2001) rather suggests that its absence in Niger or Morocco may reflect stratigraphical and/or environmental differences. $P$. arambourgi might be restricted to a Late Jurassic-earliest Cretaceous interval.

The tooth plate is referable to Ceratodus cf. humei because it shows few crests (probably five) and the crests are very shallow. This species, which may reach a very large size, is known in the Cretaceous 'Continental Intercalaire' of southern Morocco, eastern and southern Algeria, Niger, Mali, Sudan and Egypt (Tabaste, 1963; Martin, 1984; Werner, 1994; Churcher \& De Iuliis, 2001; Churcher, De Iullis \& Kleindienst, 2006).

Some ganoïd scales and circular teeth could be referable to some Semionotiformes fishes. This actinopterygian group is widely distributed in the Cretaceous continental beds of Africa.

Several fragments showing a strong reticulated ornamentation can be referred with confidence to pieces of the skull roof and opercular series of a mawsoniid coelacanth. A fragment (JAN-7) of a bony plate bearing irregularly arranged small bulbous teeth is reminiscent of the toothed parasphenoid of Mawsonia lavocati from the Kem Kem beds in Morocco figured by Wenz (1981) and Cavin \& Forey (2004), or of the toothed pterygoid of Mawsonia gigas from the Early Cretaceous of Brazil figured by De Carvalho \& Maisey (2008).

\section{4.b. Turtles and crocodiles}

El-Zouki (1980) referred a xiphoplastron from Jannawan Quarry to an undetermined pleurodiran. Many isolated crocodilian teeth cannot be referred to known genera, however, several morphotypes can be distinguished. Some very large teeth from the Tendamirah quarry have a smooth enamel and may belong to the giant pholidosaurid Sarcosuchus imperator from the El Rhaz Formation of Niger (Broin \& Taquet, 1966; Taquet, 1976; Sereno et al. 2001). Sarcosuchus is also known from Algeria and from the Douiret Formation of Tunisia, as well as from the Early Cretaceous (not later than Aptian) of Brazil (Buffetaut \& Taquet, 1977).

\section{4.c. Dinosaurs}

Only Saurischian dinosaurs have been found in the Cabao Formation. No ornithopod teeth have been found so far during our field work, although it would be premature to conclude that they are absent in the Cabao Formation given the limited size of our sampling (surface collecting). It should be noted that one isolated iguanodont tooth has been mentioned in the Douiret Formation of Tunisia by Srarfi et al. (2004). Smith \& Dalla Vecchia (2006) referred an isolated tooth from Nalut to the family Abelisauridae on the basis of a morphometrical analysis.

Two teeth from the Jawsh quarry share several very peculiar characters. The best preserved specimen (UT-JAW2; Fig. 4) is a $27 \mathrm{~mm}$ high recurved tooth slightly compressed labio-lingually with a granular enamel. The tooth is fluted and its mesial and distal carinae show extremely small serrations $(7-8 / \mathrm{mm})$. Their morphology is very close to that of the teeth of the spinosaurid Baryonyx from the Barremian of England (Charig \& Milner, 1997), although they seem to be broader in relation to the crown height than is typical for Baryonyx. We refer them to the sub-family Baryonychinae. Baryonychine spinosaurids have been described from the El Rhaz Formation in Niger, Suchomimus tenerensis Sereno et al. 1998 being probably a junior synonym of the extremely incomplete Cristatusaurus lapparenti Taquet \& Russell, 1998; according to Milner (2003), however, the spinosaur from Niger is indistinguishable from Baryonyx walkeri. Although the authors of these two papers did not fully illustrate the teeth of these dinosaurs, they mention that they bear extremely small serrations. The presence of serrations on the teeth is a good diagnostic character to separate baryonychine spinosaurids which have such serrations 


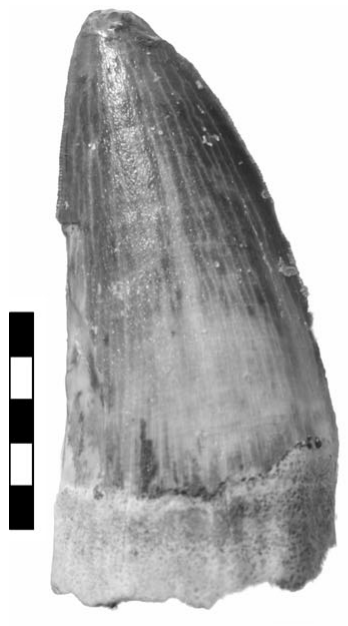

a

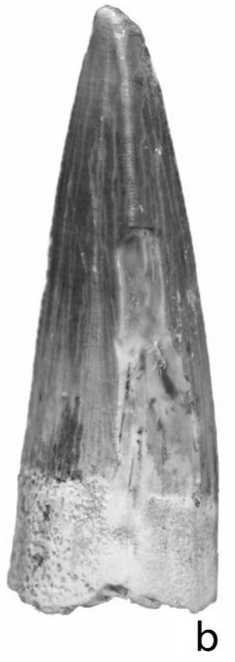

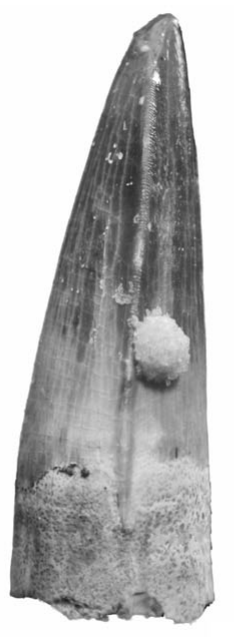

d

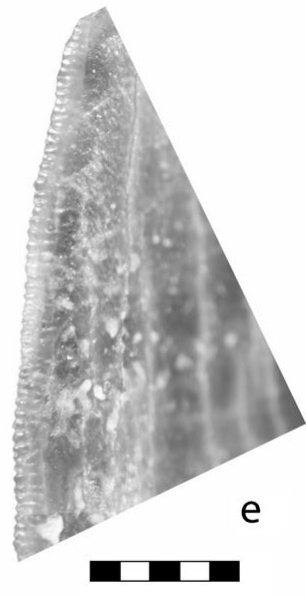

c

Figure 4. UT-JAW2; tooth of cf. Baryonyx (Jawsh Quarry, Cabao Formation, Libya) in (a) labial, (b) distal, (c) lingual and (d) mesial views. (e) Enlargement of the mesial carina. Scale bars: $10 \mathrm{~mm}$ (a-d) and $2 \mathrm{~mm}$ (e).
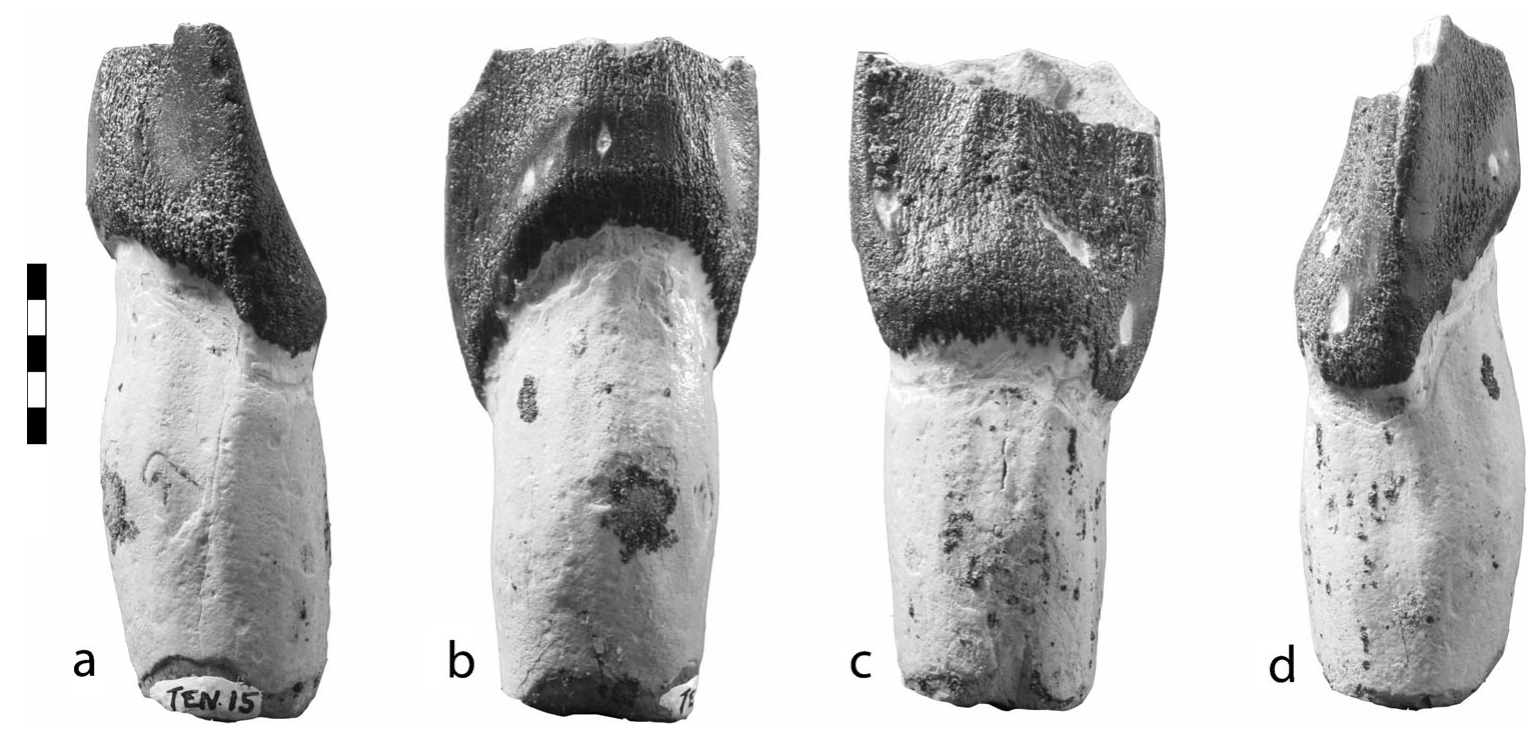

Figure 5. UT-TEN15; tooth of a ?camarasaurid sauropod, (Tendamirah Quarry, Cabao Formation, Libya) in (a) mesial, (b) labial, (c) lingual and (d) distal views; scale bar $20 \mathrm{~mm}$.

from spinosaurine spinosaurids (that is, Spinosaurus aegyptiacus, Irritator challengeri), the teeth of which have no serrations. In Africa, Spinosaurinae occur in the youngest formations of the 'Continental Intercalaire', that is, in Albian and Cenomanian deposits from Egypt, Algeria, Tunisia and Morocco, whereas older ante-Albian spinosaurids, which are known from Niger and Cameroon (J. D. Congleton, unpub. Master's thesis, Southern Methodist Univ. 1990), all belong to the Baryonichinae, suggesting a replacement during the Late Early Cretaceous (Buffetaut \& Ouaja, 2002). Buffetaut (2008) has mentioned possible spinosaurid teeth with larger serrations from the Late Jurassic of Tanzania.

A single tooth from the Tendamirah Quarry (UTTEN15, Fig. 5) can be referred to a sauropod dinosaur. It is a large (preserved height: $74 \mathrm{~mm}$ ) spatulate tooth with a wrinkled enamel, the crown of which is broken at mid-height. There is a distinct neck between the root and the crown. The labial face is convex and the lingual face is flat with two coalescing central ridges delimiting a mesial and a rostral concavity. The rostral and mesial edges of the tooth are parallel and vertical. This tooth (which belongs to the spoonlike tooth morphotype of Calvo, 1994) is clearly different from the teeth of Brachiosauridae, which show no constriction between the crown and the root, and is also different from the various morphotypes illustrated by Srarfi (D. Srarfi, unpub. Ph.D. thesis, Univ. Claude Bernard, Lyon, 2006) from the Chenini member in Tunisia. This constriction is reminiscent of the Turiasauria (cf. Royo-Torres, Cobos \& Alcala, 2006) but the crown does not show the typical heartshape of this poorly known clade. This tooth has the closest affinities with those of Camarasaurus from the Late Jurassic of the United States, as well as with teeth from the Tiouraren Formation of Niger initially described by Lapparent (1960) under 
the name of Rebbachisaurus tamesnensis and later referred to Jobaria tiguidensis by Sereno et al. (1999), although the figured teeth of Jobaria are markedly different (see next Section). We provisionally refer the tooth from Tendamirah to the family Camarasauridae (?Camarasauridae indet.). Although Rich, Molnar \& Rich (1983) mentioned camarasaurid teeth from the Late Jurassic-Early Cretaceous Kirkwood Formation in South Africa, their figures do not show any constriction at the base of the crown and their material rather suggests a brachiosaurid sauropod.

\section{Biostratigraphical implications of the vertebrate assemblage}

The ubiquitous abundance of the hybodont Priohybodus arambourgi may be interesting for biostratigraphical purposes as the genus is only known from Late Jurassic levels outside Libya and Tunisia (that is, in Yemen, Uruguay, Somalia and Ethiopia). Its last occurrence indeed was supposed to be in the overlying Kiklah Formation (see Duffin, 2001), but our field work at the site which has yielded the material studied by Duffin, as mentioned above, shows that it was actually found in the Cabao Formation, not in the Kiklah Formation. It is extremely abundant in the Cabao Formation but conspicuously absent in the Kiklah Formation, which is believed to be of Albian age (Novovic, 1977; Tekbali, 2000). It can be noted that this genus is also the most frequent hybodont in the Tunisian Douiret Formation, whereas a much more diversified shark fauna is known from the Chenini and Oum ed Diab members of Late Aptian to Albian age (Cuny et al. 2004); even though this may be linked to environmental differences as Priohybodus is considered a freshwater form, it is interesting to note that it is absent from the Tunisian formations of supposed Aptian-Albian age and that its last well-dated occurrence is in the Douiret Formation (Cuny et al. 2004), that is, in the Berriasian to Early Aptian of Tunisia. The record of Priohybodus would thus instead suggest an age close to the beginning of the Cretaceous for the Douiret and Cabao formations.

The presence of a baryonichine spinosaurid also suggests an ante-Albian age, as African baryonichines are so far known only from the supposedly Aptian El Rhaz Formation of Niger and the Koum Formation of Cameroon, the vertebrate assemblage of which seems very close to the El Rhaz fauna (Taquet, 1984; J. D. Congleton, unpub. Master's thesis, Southern Methodist Univ. 1990); European baryonichines are known from the Hauterivian to the Early Aptian in England, Portugal and Spain (Milner, 2003; Buffetaut, 2007; Canudo et al. 2008). The rich Albian and Cenomanian deposits of North Africa have so far yielded only spinosaurine spinosaurids (Cavin et al. 2010; Buffetaut \& Ouaja, 2002) and spinosaurids are so far unknown from the European Albian localities. The precise age of the El Rhaz Formation is not so clear: it was considered as Barremian to Late Albian by Taquet (1976), who suggested an Aptian age, an opinion largely followed by subsequent authors, although Taquet's suggestion was based on the referral to the Aptian by Busson (1967) of an isolated ornithopod tooth found in Tunisia by Lapparent. It has since been demonstrated that this iguanodontid tooth (found in the Oum ed Diab member of the Ain Guettar Formation, a few metres below the Cenomanian marine deposits) was more likely Albian, after the discovery of ammonites in the vicinity (D. Srarfi, unpub. Ph.D. thesis, Univ. Claude Bernard, Lyon, 2006). However, iguanodontid teeth are also known in the older Douiret Formation (Srarfi et al. 2004). Thus Taquet's main argument for an Aptian age seems weaker and his 'Barremian to Albian' interval for the El Rhaz Formation is likely, although an older age is not impossible as the lower part of the formation is not stratigraphically constrained.

The presence of a sauropod spatulate tooth in Libya would also suggest an age older than Aptian for the Cabao Formation. Although the best known camarasaurid genera (Camarasaurus and Haplocanthosaurus) are restricted to the Late Jurassic of the United States, isolated bones and teeth from Europe are slightly younger (Berriasian of Western France: cf. Le Loeuff, Buffetaut \& Merser, 1996; Colin et al. 2004). The youngest possible camarasaurids known so far are Hauterivian to Early Barremian in age in Europe (locality of El Pelejon in Galve, Spain: cf. Sanz et al. 1987); incomplete spatulate teeth occur in the Tiouraren Formation of Niger, which underlies the El Rhaz Formation and the age of which has been strongly disputed by Rauhut \& Lopez-Arbarello (2009), who, on the basis of the evolutionary grade of the dinosaurs, suggest a Late Middle Jurassic age for this unit. El Rhaz sauropods include the rebbachisaurid Nigersaurus taqueti and an undescribed titanosaur (Taquet, 1976; Sereno et al. 1999), but spoon-like teeth have been reported only in the older Tiouraren Formation (see Lapparent, 1960). Sereno et al. (1999) have described the sauropod Jobaria in this formation; the single illustrated tooth shows serrations and is markedly different from the Libyan tooth and also from the spoon-like teeth illustrated by Lapparent; this suggests that the spoon-like teeth from Niger may not belong to Jobaria but to a second sauropod, possibly a camarasaurid. The absence in the Cabao Formation of ornithopod teeth which are extremely abundant in the El Rhaz Formation (but absent in the Tiouraren Formation) can hardly be taken into consideration given the small size of our sampling.

\section{Conclusions}

The vertebrate assemblage from the Cabao Formation thus strongly suggests an Ante-Aptian age, possibly Hauterivian to Barremian like the Douiret Formation of Tunisia. It can be suggested that the El Rhaz Formation of Niger, which shows some vertebrates in common with the Cabao Formation, may be slightly younger that the latter (absence of Priohybodus and sauropods with large spatulate teeth; abundance of iguanodontids) 
and that the Tiouraren Formation may be slightly older but possibly still Cretaceous (presence of sauropods with spatulate teeth). In Tunisia, the younger Ain Guettar Formation (Aptian-Albian) has yielded a very different dinosaur assemblage (spinosaurines, advanced titanosauriforms). This review confirms the strong potential of fossil vertebrates to correlate sites in the Continental Intercalaire across Africa. Contrary to what was initially suggested by Lapparent (1960) who envisioned a rather uniform fauna throughout these deposits, it is now widely recognized that important changes occurred in the vertebrate assemblages between the earliest Cretaceous and the Cenomanian. Although not enough assemblages have been described in detail, it seems that vertebrates may be useful to establish the stratigraphical framework of the Continental Intercalaire and its equivalents in central, eastern and northern African Cretaceous basins.

Acknowledgements. We wish to thank the NOC of Libya for having authorized TOTAL to perform the sedimentological field work and NOC and TOTAL Libye for permission to publish this paper. We thank Gilles Cuny (Geological Museum, Copenhagen) for sharing information on the age of the Tunisian Douiret Formation. The senior author thanks colleagues from the Office National des Mines in Tunis (M. Bel Hadj, M. Ouaja, D. Srarfi) for their invitations and joint field work in southern Tunisia. Thanks to Didier Cave for the drafting of the Geology section and to Gilles Cuny and an anonymous reviewer for their constructive remarks.

\section{References}

BARALE, G. \& OUAJA, M. 2002. La biodiversité végétale des gisements d'âge Jurassique supérieur-Crétacé inférieur de Merbah el Asfer (Sud-Tunisien). Cretaceous Research 23, 707-37.

Benest, M., Gaspard, D. \& Ghali, M. 1996. Les brachiopodes de l'avant-pays ouest-algérien lors de la phase transgressive maximale du Berriasien supérieur; systématique, environnement et paléogéographie. Géobios 29, 13-34.

Benton, M. J., Bouaziz, S., Buffetaut, E., Martill, D., OuAJA, M., Soussi, M. \& TRueman, C. 2000. Dinosaurs and other fossil vertebrates from fluvial deposits in the Lower Cretaceous of southern Tunisia. Palaeogeography, Palaeoclimatology, Palaeoecology 157, 227-46.

Bouaziz, S., Buffetaut, E., Ghanmi, M., JaEger, J.-J., MARTIN, M., MAZIN, J.-M. \& TONG, H. 1988. Nouvelles découvertes de vertébrés fossiles dans l'Albien du Sud Tunisien. Bulletin de la Société géologique de France 4, 335-9.

DE Broin, F. \& Taquet, P. 1966. Découverte d'un crocodilien nouveau dans le Crétacé inférieur du Sahara. Comptes Rendus de l'Académie des Sciences de Paris D 262, 2326-9.

BuffETAUT, E. 2007. The spinosaurid dinosaur Baryonyx (Saurischia, Theropoda) in the Early Cretaceous of Portugal. Geological Magazine 144, 1021-5.

Buffetaut, E. 2008. Spinosaurid teeth from the Late Jurassic of Tendaguru, Tanzania, with remarks on the evolutionary history and biogeographical history of the Spinosauridae. In Mid-Mesozoic Life and Environments, Cognac (France) (eds J.-M. Mazin, J. Pouech, P.
Hantzpergue \& V. Lacombe), pp. 26-8. Documents des Laboratoires de Géologie de Lyon 164.

Buffetaut, E. \& OuAJA, M. 2002. A new specimen of Spinosaurus (Dinosauria, Theropoda) from the Lower Cretaceous of Tunisia, with remarks on the evolutionary history of the Spinosauridae. Bulletin de la Société géologique de France 173, 415-21.

Buffetaut, E. \& TAQUeT, P. 1977. The giant crocodilian Sarcosuchus in the Early Cretaceous of Brazil and Niger. Palaeontology 28, 203-8.

Burollet, P. F. 1963a. Saharan symposium, Field trip Guide book of the excursion to Jebel Nefusa. Tripoli: Petroleum Exploration Society of Libya, $17 \mathrm{pp}$.

Burollet, P. F. 1963b. Discussion sur la Stratigraphie Libyenne. Revue de l'Institut Français du Pétrole, Paris, 18, 1323-1328.

Burollet, P. F. \& Manderscheid, G. 1965. Le Crétacé inférieur en Tunisie et en Libye. Mémoires BRGM 34, 785-94.

Buscalioni, A. D., Fregenal, M. A., Bravo, A., PoyatoAriza, F. J., SANchíz, B., BÁEz, A. M., CAMbra Moo, O., Martín Closas, C., Evans, S. E. \& MARUGÁn LOBÓN, J. 2008. The vertebrate assemblage of Buenache de la Sierra (Upper Barremian of Serrania de Cuenca, Spain) with insights into its taphonomy and palaeoecology. Cretaceous Research 29, 687-710.

Busson, G. 1967. Le Mésozoïque saharien, lère partie: l'extrême Sud-Tunisien. 'Centre Recherche Zones arides', Centre National de la Recherche Scientifique édit., Paris, 8, 194 pp.

CAlvo, J. O. 1994. Jaw mechanics in sauropod dinosaurs. Gaia 10, 183-93.

CAnudo, J. I., Gasulla, J. M., GÓMEZ-FernándeZ, D., Ortega, F., SAnz, J. L. \& YAgǗ, P. 2008. Primera evidencia de dientes aislados atribuidos a Spinosauridae (Theropoda) en el Aptiano inferior (Cretácico Inferior) de Europa: Formación Arcillas de Morella (España). Ameghiniana 45, 649-52.

CAVIN, L. \& FOREY, P. L. 2004. New mawsoniid coelacanth (Sarcopterygii, Actinistia) remains from the Cretaceous of the Kem Kem beds, SE Morocco. In Mesozoic Fishes III - Systematics, Paleoenvironments and biodiversity (eds A. Tintori \& G. Arratia), pp. 493-506. Dr Pfeil Verlag.

Cavin, L., Tong, H., Boudad, L., Meister, C., Piuz, A., TABouelle, J., AARAB, M., AMiot, R., Buffetaut, E., Dyke, G., HuA, S. \& Le Loeuff, J. 2010. Vertebrate assemblages from the early Late Cretaceous of southeastern Morocco: an overview. Journal of African Earth Sciences, doi:10.1016/j.jafrearsci.2009.12.007, in press.

CHARIG, A. J. \& MiLner, A. C. 1997. Baronyx walkeri, a fish eating dinosaur from the Wealden of Surrey. Bulletin of the Natural History Museum, Geology Series 53, 11-70.

Churcher, C. S. \& De IULiIs, G. 2001. A new species of Protopterus and a revision of Ceratodus humei (Dipnoi: Ceratodontiformes) from the Mut Formation of eastern Dakhleh Oasis, Western Desert of Egypt. Journal of Paleontology 44, 305-23.

Churcher, C. S., DE IUlis, G. \& Kleindienst, M. R. 2006. A new genus for the dipnoan species Ceratodus tuberculatus Tabaste, 1963. Geodiversitas 28, 635-47.

Colin, J. P., El Albani, A., Fursich, F. T., MartinClosas, C., MAZIN, J. M. \& BILlON-BRUYAT, J. P. 2004. Le gisement "Purbeckien" de vertébrés de Chervesde-Cognac, Charente (SW France): nouvelles données biostratigraphiques. Comptes Rendus Palévol 3, 9-16.

Cuny, G., Ouaja, M., SRarfi, D., Schmitz, L., Buffetaut, E. \& Benton, M. J. 2004. Fossil sharks from the Early 
Cretaceous of Tunisia. Revue de Paléobiologie, special volume 9, 127-42.

DALla VeCCHIA, F. M. 1995. Second record of a site with dinosaur skeletal remains in Libya (northern Africa). Natura Nascosta 11, 16-19.

De Carvalho, M. S. S. \& Maisey, J. G. 2008. New occurrence of Mawsonia (Sarcopterygii: Actinistia) from the Early Cretaceous of the Sanfranciscana Basin, Minas Gerais, southeastern Brazil. In Fishes and the Break-up of Pangaea (eds L. Cavin, A. Longbottom \& M. Richter), pp. 109-44. Geological Society of London, Special Publication no. 295.

Desio, A. 1950. Bibliografia geologica italiana dell'Africa sino al 1948 incluso. Collezione scientifica e documentaria dell'Africa italiana $\mathbf{1 5}, 1-83$.

Duffin, C. J. 2001. The hybodont shark, Priohybodus d'Erasmo, 1960 (Early Cretaceous, northern Africa). Zoological Journal of the Linnean Society 133, 303-8.

EL-ZOUKI, A. Y. 1980. Stratigraphy and lithofacies of the continental clastics (Upper Jurassic and Lower Cretaceous) of Jabal Nafusah, NW Libya. In The Geology of Libya, Vol. II (eds M. J. Salem \& M. T. Busrewil), pp. 393-418. London: Academic Press.

Fatmi, A. N., Eliagoubi, B. A. \& Hammuda, O. S. 1980. Stratigraphic nomenclature of the Pre Upper Cretaceous Mesozoic rocks of Jabal Nafusah, NW Libya. In Second Symposium on the Geology of Libya, Vol. 1 (eds M. J. Salem \& M. T. Busrewil), pp. 57-66. London: Academic Press.

HAMMUDA, O. S. 1969. Jurassic and Lower Cretaceous rocks of Central Jabal Nefusa, Northewestern Libya. Tripoli, Libya: The Petroleum Exploration Society of Libya, $79 \mathrm{pp}$.

KILIAN, C. 1931. Des principaux complexes continentaux du Sahara. Comptes-rendus sommaires des séances de la Société géologique de France 9, 109-11.

Kriwet, J. \& SchmitZ, L. 2005. New insight into the distribution and palaeobiology of the pycnodont fish Gyrodus. Acta Palaeontologica Polonica 50, 49-56.

DE LAPPARENT, A. F. 1951. Découverte de Dinosauriens, associés à une faune de Reptiles et de Poissons, dans le Crétacé inférieur de l'Extrême Sud tunisien. ComptesRendus de l'Académie des Sciences de Paris 232, 1430-2.

DE LAPPARENT, A. F. 1960. Les Dinosauriens du "Continental Intercalaire" du Sahara central. Mémoires de la Société géologique de France (Nouvelle Série) $\mathbf{8 8 A}$, $1-57$.

Le Loeuff, J., Buffetaut, E. \& Merser, C. 1996. Découverte d'un dinosaure tithonien dans la région de Cognac (Charente, France). Géologie de la France 2, 79-81.

MARTIN, M. 1984. Deux Lepidosirenidae (Dipnoi) crétacés du Sahara, Protopterus humei (Priem) et Protopterus protopteroides (Tabaste). Paläontologische Zeitschrift 58, 265-77.

MiLNER, A. C. 2003. Fish-eating theropods: a short review of the systematics, biology and palaeobiogeography of spinosaurs. Actas de las II Jornadas Internacionales sobre Paleontologia de Dinosaurios y su Entorno (2001) (eds P. Huerta Hurtado \& F. Torcida FernandezBaldor), pp. 129-38. Salas de Los Infantes: Colectivo Arqueologico-Paleontologico de Salas.

Novovic, T. 1977. Sheet Nalut (NI 32-4) Geological Map of Libya, scale 1:250 000, Explanatory booklet. Tripoli: Industrial Research Centre, $68 \mathrm{pp}$.

O’Leary, M. A., Roberts, E. M., Head, J. J., Sissoko, F. \& BOUARE, M. L. 2004. Titanosaurian (Dinosauria:
Sauropoda) remains from the "Continental intercalaire" of Mali. Journal of Vertebrate Paleontology 24, 923-30.

Ouaja, M., Ferry, S., Barale, G. \& SRARFi, D. 2002. Faciès de dépôt du Jurassique et du Crétacé du bassin de Tataouine (Sud-Est de la Tunisie). Livret guide de l'excursion organisée par le Service Géologique de Tunisie et l'Association des Sédimentologistes Français, publication de l'Office National de Mines, $99 \mathrm{pp}$.

Perea, D., Ubilla, M., Rojas, A. \& Goso, C. A. 2001. The West Gondwanan occurrence of the hybodontid shark Priohybodus and the Late Jurassic-Early Cretaceous age of the Tacuarembó Formation, Uruguay. Palaeontology 44, 1227-35.

PERVINQUiÈRE, L. 1912. Sur la géologie de l'extrême sudtunisien et de la Tripolitaine. Bulletin de la Société géologique de France 4, 143-93.

Peybernès, B., Vila, J. M., Souquet, P., Charrière, A., Ben Youssef, M., Zarbout, M. \& Calzada, S. 1996. Trois gisements de brachiopodes dans le Crétacé inférieur tunisien. Batalleria 6, 45-58.

Rauhut, O. W. M. \& LóPEZ-Arbarello, A. 2009. Considerations on the age of the Tiouaren Formation (Iullemmeden Basin, Niger,Africa): Implications for Gondwanan Mesozoic terrestrial vertebrate faunas. $\mathrm{Pa}$ laeogeography, Palaeoclimatology, Palaeoecology 271, 259-67.

REES, J. \& UNDERWOOD, C. J. 2008. Hybodont sharks of the English Bathonian and Callovian (Middle Jurassic). Palaeontology 51, 117-47.

Rich, T. H. V., Molnar, R. E. \& Rich, P. V. 1983. Fossil vertebrates from the Late Jurassic of Early Cretaceous Kirkwood Formation, Algoa Basin, southern Africa. Transactions of the Geological Society of South Africa 86, 281-91.

Robaux, A., Choubert, G., Flandrin, J. \& Drosdoff, A. 1942. Notice sur la carte géologique et hydrogéologique provisoire de la Tunisie. Feuilles Dehibat et Djenein au 1/200 000e. Direction des Travaux Publics de Tunisie, $57 \mathrm{pp}$.

Royo-Tores, R., Cobos, A. \& Alcala, L. 2006. A Giant European Dinosaur and a New Sauropod Clade. Science 314, 1925-7.

Rubino, J. L., Lafont, F., Métais, E., Blanpied, C., FERry, S., OuAJA, M. \& SBETA, A. 2009. Large scale tidal dunes complex of Aptian (?)-Albian age along Nafusah cliff, Libya-Tunisia. 12ème congrès Français de Sédimentologie - Rennes 2009. Livres des résumés, Publ. ASF, 64, p. 289.

Sanz, J. L., Buscalioni, A. D., Casanovas, M. L. \& SANTAFÉ, J. V. 1987. Dinosaurios del Cretácico Inferior de Galve (Teruel, España). Estudios Geológicos Volumen Extraordinario Galve-Tremp, 45-64.

SASSI, P. 1942. Sui Fossili di Due Giascinentie Wealdiani della Tripolitania. Annali Museo Libico Storia Naturale 3 .

Sereno, P. C., Wilson, J. A., LARSSON, H. C. E., DutheIL, D. B. \& SuES, H.-D. 1994. Early Cretaceous dinosaurs from the Sahara. Science 266, 267-71.

Sereno, P. C., Beck, A. L., Dutheil, D. B., Gado, B., Larsson, H. C. E., LyON, G. H., Marcot, J. D., Rauhut, O. W. M., SADleir, R. W., SidOR, C. A., VARRICCHIO, D. J., WiLSON, G. P. \& WiLSON, J. A. 1998. A long-snouted predatory dinosaur from Africa and the evolution of the spinosaurids. Science 282, 1298-1302.

Sereno, P. C., Beck, A. L., Dutheil, D. B., LARsson, H. C. E., LyON, G. H., Moussa, B., SADleIR, R. W., SidOR, C. A., Varricchio, D. J., Wilson, G. P. \& Wilson, J. A. 1999. Cretaceous sauropods from the Sahara and 
the uneven rate of skeletal evolution among dinosaurs. Science 286, 1342-7.

Sereno, P. C., Larsson, H. C. E., Sidor, C. A. \& Gado, B. 2001. The giant crocodyliform Sarcosuchus from the Cretaceous of Africa. Science 294, 1516-19.

Smith, J. B. \& DALla Vecchia, F. M. 2006. An abelisaurid (Dinosauria: Theropoda) tooth from the Lower Cretaceous Chicla formation of Libya. Journal of African Earth Sciences 46, 240-4.

SMith, J. B. \& LAMANNA, M. C. 2009. Abelisauroid dinosaurs from the Early Cretaceous of Libya. Geological Society of America, Abstracts with Programs 41, 242.

SMith, J. B., LAMANNA, M. C., Lacovara, K. J., DODSON, P., SMith, J. R., PoOle, K. J., GIEGENGACK, R. \& ATtiA, Y. 2001. A giant sauropod dinosaur from an Upper Cretaceous Mangrove deposit in Egypt. Science 292, 1704-6.

Smith, J., TShakreen, S., Rasmussen, S. \& Lamanna, M. 2006. New dinosaur discoveries from the Early Cretaceous of Libya. Journal of Vertebrate Paleontology 26(3), 126

Srarfi, D., Ouaja, M., Buffetaut, E., Cuny, G., Barale, G., FERRY, S. \& FARA, E. 2004. Position stratigraphique des niveaux à vertébrés du Mésozoïque du Sud-Est de la Tunisie. Notes du Service Géologique de Tunisie $\mathbf{7 2}$, $5-16$.

Stromer, E. 1936. Ergebnisse der Forschungsreisen Prof. E. Stromers in den Wüsten Agyptens. VII. BaharijeKessel und -Stufe mit deren Fauna und Flora. Eine ergänzende Zusammenfassung. Abhandlungen der Bayerischen Akademie der Wissenschaften, Mathematischnaturwissenschaftliche Abteilung $n$. f. 33, 1-102.

TABASTE, N. 1963. Etude de restes de poissons du Crétacé saharien. Mémoire, IFAN 68, mélanges ichthyologiques, 437-85.

TAQUET, P. 1976. Géologie et paléontologie du gisement de Gadoufaoua (Aptien du Niger). Cahiers de Paléontologie du C. N. R. S., 191 pp.

TAQUET, P. 1984. Une curieuse spécialisation du crâne de certains dinosaures carnivores du Crétacé: le museau long et étroit des Spinosauridés. Comptes Rendus de l'Académie des Sciences de Paris II 299, 217-22.

TAQuet, P. \& RUSSELL, D. A. 1998. New data on spinosaurid dinosaur from the Early Cretaceous of the Sahara. Comptes Rendus de l'Académie des Sciences de Paris 327, 347-53.

TekBali, A. O. 2000. Pollen and spores from Subsurface Albian of the Kiklah Formation, NW Libya. Abstract, International Workshop on North African Micropaleontology for petroleum exploration. University College London, 21-25 August 2000, p. 70

WeNZ, S. 1981. Un coelacanthe géant, Mawsonia lavocati Tabaste, de l'Albien-base du Cénomanien du Sud marocain. Annales de Paléontologie (Vertébrés) 67, 1-20.

WERNER, C. 1994. Die kontinentale Wirbeltierfauna aus der unteren Oberkreide des Sudan (Wadi Milk Formation). Berliner geowissenschaftliche Abhandlungen (E) 13, 221-49. 